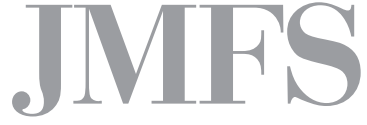

Journal of Management and Financial Sciences
Volume XI

Issue 32 (June 2018)

pp. $115-126$

Warsaw School of Economics

Collegium of Management and Finance

Józef Haczyński, Kazimierz Ryć, Zofia Skrzypczak

Faculty of Management

University of Warsaw

\title{
"Zdrowie 2017" [Health 2017] Nurses and Doctors in the Polish Healthcare System
}

\begin{abstract}
Healthcare systems operate properly as long as there are enough skilful health professionals available. This paper compares the population of doctors and nurses in the healthcare system in Poland and in other European countries. We used statistical data gathered by the Organisation for Economic Cooperation and Development (OECD), Statistics Poland, Ministry of Health, as well as materials from the General Medical Council, and the Nursing and Midwifery Council in Poland. We made an attempt to find out why Poland ranks so low in the lists showing the number of practising doctors and nurses per 1,000 population. We identified the main sources of "inflows" (graduates of medical and nursing schools) and "outflows" (retirement, migration, people leaving medical professions) into/ from the pool of health professionals. Our goal was also to specify which areas necessitate systemic changes to increase the number of practising doctors and nurses. We decided that institutional changes are also needed: increasing the number of students admitted to medical schools, better working conditions for medical professionals, incentives to return to Poland, etc. Such changes combined with rising public expenditure may improve the performance of the healthcare system in Poland.
\end{abstract}

Keywords: human resources, healthcare, nurses, doctors, shortages of medical professionals JEL Classification Codes: I11, J21 


\section{Introduction}

One of the major challenges of contemporary healthcare consists in ensuring adequate access to medical services. Effective performance of the system depends on many macroeconomic, demographic, and legal factors. Healthcare professionals are one of the fundamental constituents of the healthcare systems, which operate correctly only when they have sufficient pools of skilful workforce. The latter dictates the framework within which the array of medical services can be expanded; also, the right to benefit from top quality healthcare services depends on the availability and quality of medical professionals (WHO, 2016). Skilful management of contemporary healthcare institutions largely depends on proper human resource management due to their limited availability and the dependence between their size and quality and the health and life of people or the impact of adequate distribution of human and material resources across different levels of medical services.

The term "medical profession" covers occupations engaged in actions aimed at delivering medical services that protect the health of patients. There are legal regulations which help distinguish medical professions, such as: a medical doctor and a dentist, a nurse and a midwife, laboratory technician, a paramedic, and a pharmacist [Czerw, 2011]. Since medical doctors and nurses make the biggest groups of medical professionals, our further considerations will focus on these two groups. Members of all the above mentioned professional groups practise occupations which are specific and belong to the so-called professions of high public trust. Healthcare professionals are entrusted with very specific public tasks and their duties are closely connected with acting in the public interest where due care must be exercised.

Today, many countries worldwide suffer from an increasing shortage of trained healthcare workers. The problem is caused by the growing demand for medical services resulting, inter alia, from the increased life expectancy and the rise of chronic diseases that accompany the ageing of societies. Together with the increasing life expectancy, progress in medical sciences, and better access to healthcare services we can observe an increasing number of chronic diseases and disabilities whose costs of treatment grow rapidly not only due to the cost of medicines or medical procedures but also because of the growing number of medical appointments and consultations and the need to ensure highly specialist nursing care to elderly people (Araujo, Evans, Maeda, 2016). At the same time, we witness skilled healthcare professionals migrating to richer economies by which the shortages in the healthcare workforce in economically less developed countries become even deeper [Buchan, Wismar, Glinos, Brenner, 2014]. Detailed analysis into the changes in human resources in the healthcare sector helps decision-makers adopt adequate measures and introduce corrective actions in the healthcare system as well as at the level of higher education, labour market, remuneration, etc.; these changes may produce expected outcomes by providing a more comprehensive access to services rendered by healthcare professionals. 
The paper aims at investigating the resources of medical doctors and nurses in the Polish healthcare system and comparing them to other European countries; we will also identify how intensely they are used, why in Poland there is a high proportion of doctors and nurses trained but not practising their professions and what can be done to improve the currently unsatisfactory situation.

Based on the data of the Organisation for Economic Cooperation and Development (OECD), Statistics Poland, the Ministry of Health and materials of the General Medical Council, and the Nursing and Midwifery Council in Poland we analysed how many medical doctors and nurses have the right to practise their respective occupations and how many of them are practising doctors and nurses in the Polish healthcare system and in the European OECD countries; we identified "inflows" and "outflows" to/from categories, such as a "practising medical doctor" and a "practising nurse".

Collecting knowledge about a relatively small group (compared to other European countries) of practising medical doctors and nurses in Poland and detailed examination of the group may facilitate delineating corrective actions within the healthcare system as well as what should be done at the level of higher education, labour market, salaries, etc.

\section{Doctors and nurses: Poland and other European OECD countries}

All healthcare professionals authorised to practise their professions, also doctors and nurses, are registered in respective registers kept, in this case, by the General Medical Council, and the Nursing and Midwifery Council. Not all healthcare professionals authorised to practise their occupations in Poland remain within the Polish healthcare system.

Table 1 gives the numbers of medical doctors and nurses authorised to practise their professions who were employed in the healthcare system in Poland over the period 2011-2016. We also calculated the proportion of medical doctors and nurses who actually practise their professions.

In the years 2011-2016 the number of doctors and nurses licensed to practise their professions grew systematically (although at different rates): the number of doctors increased from $136.2 \mathrm{k}$ in 2011 to $145 \mathrm{k}$ in 2016 (an increase of ca. 6.5\%), while the number of nurses increased from $282.5 \mathrm{k}$ in 2011 to $288.5 \mathrm{k}$ in 2016 (an increase of ca. 2\%).

Over the same period, the number of doctors employed in the healthcare system grew from $82.4 \mathrm{k}$ to almost $90 \mathrm{k}$, i.e. by ca. $9 \%$ while the number of working nurses dropped from $194.2 \mathrm{k}$ to $184.4 \mathrm{k}$, i.e. by ca. $5 \%$.

The share of actively practising doctors in the overall population of doctors authorised to practise their profession slightly fluctuated over the years 2011-2015 but remained within the interval $59.7-60.7 \%$ and in 2016 it grew to $62 \%$. In the period covered by the survey 
there was a high percentage, ca. $40 \%$, of medical doctors who did not practise their trained profession in Poland.

The share of practising nurses in the total population of licensed nurses exhibited a clearly decreasing trend from $70 \%$ in 2012 to $63.9 \%$ in 2016 , meaning a drop of over 6 percentage points.

Recently the percentage of doctors and nurses licensed to practise their professions who do not work in the Polish healthcare system is, unfortunately, very high and we need to investigate into the reasons for the phenomenon and quickly adopt adequate measures. Those who do not practise their trained professions could quickly expand human resources available in the Polish healthcare system without having to wait many years until new generations of doctors and nurses graduate and accumulate professional experience, which for doctors takes minimum 10 years and for nurses ca. 6-8 years. Detailed studies are needed to explain why doctors and nurses leave their professions.

International comparisons between healthcare sectors in different countries focused on doctors and nurses employed in them use indicators informing about the number of practising professionals per 1,000 population of a given country.

Diagram 1 shows the number of practising doctors per 1,000 population in European OECD countries in the years 2000 and 2015.

In the ranking of practising doctors per 1,000 population in European countries in 2015 Poland ranks last but one (only in Turkey the situation is worse) - the indicator in question increased in Poland over the past 16 years from 2.2 in 2000 to only 2.3 in 2015.

We need to stress that in the same period most European countries reported an increase - often quite substantial - in the number of practising doctors per 1,000 population (e.g. Austria - from 3.9 in 2000 to 5.1 in 2015; Norway - from 3.4 to 4.4; Lithuania - from 3.6 to 4.3 ; Germany - from 3.3 to 4.1 ).

The picture for practising nurses per 1,000 population in European OECD countries is similar (Diagram 2).

On the list of practising nurses per 1,000 population in European OECD countries Poland also occupies one of the last places; over the last 16 years the indicator in question grew only from 5.0 in 2000 to 5.2 in 2015 (Turkey, Greece, and Latvia reported lower indicators). Like in the case of practising doctors, most European countries saw increasing numbers of practising nurses per 1,000 population, e.g., Switzerland from 12.9 in 2000 to 18 in 2015; Denmark - from 12.4 to 16.7; Finland - from 10.7 to 14.7; France - from 6.7 to 9.9. Slovakia, where the indicator decreased from 7.4 in 2000 to 5.7 in 2015 was the only exception.

\section{Causes of healthcare workforce shortages in Poland}

When seeking to explain negative - compared to other European countries - trends in human resources in the healthcare sector observed in Poland we investigated the inflows and outflows of healthcare workers. 
"Inflows" of human resources into the healthcare sector include: graduates of medical and nursing faculties at schools of medicine, immigrants or healthcare workers who come back to their homeland having worked some time abroad. On the other hand, "outflows" from the pool of doctors and nurses are caused by: deaths, retirement, emigration, giving up the profession and moving to non-medical sectors in the same country, and losing the right to practise a regulated profession [Gamzu et al., 2016].

The biggest regular streams of doctors' and nurses' inflow into the sector from medical schools/faculties. The distant place of Poland in the European ranking of practising doctors and nurses per 1,000 population is largely caused by the fact that the country has one amongst the lowest indicators of the number of graduates of medical and nursing schools per 1,000 population (Diagrams 3 and 4).

In the ranking of the number of graduates of medical faculties per 100,000 population in the European OECD countries (Diagram 3) Poland ranks in the bottom with the indicator of 10.2. A similar number of graduates of medical faculties is reported by France (10.0), while lower indicators were reported only by Greece (9.3) and Turkey (8.9).

In the list showing the population of graduates of nursing faculties per 100,000 population in European OECD countries (Diagram 4) Poland occupies a rather distant place (although not as distant as for graduates of medical departments) - with the indicator of 32.1. Lower indicators were reported, inter alia, for the United Kingdom (27.0), Spain (23.2), Italy (20.6), the Czech Republic (15.8), and Luxembourg (12.8).

The "inflow" into the groups of practising medical doctors and nurses is also generated by immigration flows into a given country. However, how can we expect such "inflows" of the healthcare workforce into Poland to be meaningful when in the list showing the share of practising doctors - foreigners trained abroad the indicator for Poland is $1.8 \%$ (only Italy $-0.8 \%$ and Turkey $-0.2 \%$ are doing worse). Top ranking countries are: Ireland - with 39\% share of foreign medical doctors, Norway - 38.1\%, Sweden, Switzerland, and the UK - ca. 27\%, and Finland - ca. 20\% (OECD, 2017).

In a similar ranking for nurses, OECD statistics does not even provide data for Poland. In the same year the share of foreign nurses in the total pool of nurses in, e.g., Switzerland reached 18.7\%, in Norway - 9.1\%, in Germany - 7.2\%, and in Italy - 5.7\% (OECD, 2017).

This unfavourable situation results largely from the legal framework for diploma recognition in Poland. Potential candidates are often discouraged by complex procedures they have to comply with in the process to finally get the right to practise a regulated profession. The need to complete an internship programme, difficulties involved in learning the language and little attractive, compared to other countries in Europe, remuneration offered to doctors and nurses only exacerbate the problem.

On the side of the "outflows" from resources of practising doctors and nurses there are the so-called natural outflows caused by deaths and retirement of the healthcare workforce.

Diagram 5 shows the age structure of doctors and nurses licensed to practise in the healthcare sector in 2016 (as of 31 December 2016). 
More than 22\% doctors and 9.5\% nurses licensed to practise their respective professions were 65 and older; more than 21\% doctors and almost 28\% nurses were aged between 55 and 64 . Fewer than $19 \%$ doctors and only $9 \%$ nurses with the right to practise their regulated professions were young people below 35 years of age. This is a highly worrying picture, which confirms there are too few young people in these vital medical professions to replace the older generations of doctors and nurses and ensure proper functioning of the healthcare system [Haczyński, Skrzypczak, Winter, 2017].

By comparing the indicator showing the share of doctors from the age group 55+ in the total population of doctors, which in 2016 amounted to $43.3 \%$, with the data from international statistics we may conclude that a higher or similar share of this age group was found only in the following countries: Italy $-53.3 \%$, Estonia $-46.7 \%$, France $-46.6 \%$, Latvia - 46.2\%, Belgium - 44.4\%, and Germany - 43.9\%, as of 2015 (OECD, 2017). Many years of education and professional training needed to perform these professions will soon create a generation gap, which will seriously restrict learning opportunities from older, experienced medical staff.

Emigration generates another stream of outflow of doctors and nurses licensed to practise their professions. Nowadays, medical staff emigration is an issue to almost all the EU economies. Every year Poland, especially after it has joined the European Union and following the opening of the labour markets in the "old EU", reports the emigration of significant groups of medical professionals. In the literature we can read that political developments in Europe (e.g, Poland's EU accession) have enabled migration; while economic reality, mainly differences in the income of medical professionals between Poland (and in other post-Communist countries) and highly developed countries of Western Europe have triggered actual flows [Kautsch, 2013].

It is hard to specify how many Polish doctors and nurses have left the country to work abroad - no reliable data is available. However, data from Biuletyny Statystyczne [Statistical Bulletins] of the Ministry of Health lets us conclude that immediately after Poland had joined the European Union, the number of medical doctors practising in Poland in 2005 decreased by ca. 9,500 compared to the data for 2004 [Golinowska, Kocot, Sowa, 2013].

The number of certificates that confirm professional skills and are issued by professional Councils (the General Medical Council, Nursing and Midwifery Council) is a rough estimate and the measure of interest in leaving the country. In accordance with the data from the report of the General Medical Council, in 2015 they issued 9,337 certificates to confirm professional skills of doctors seeking recognition for their skills in other EU countries. It accounted for $7.1 \%$ of the practising medical doctors (Zgliczynski, Cianciara, Śliż, Rostkowska, Pinkas, 2016). In accordance with the data, the Nursing and Midwifery Council issued 16,115 "certificates necessary for the recognition of professional qualifications" between 1.05.2004 and 31.12.2013 (Zabezpieczenie, 2015). Unfortunately, neither for medical doctors nor for nurses the number of certificates is a reliable measure as they often start working in other countries without asking for such a certificate in Poland. Polish medical professionals move mainly 
to the following EU countries: the UK, Ireland, Germany, Sweden, Norway, and Denmark [Golinowska, 2012]. Medical staff outflows are especially unfavourable for the future of the Polish healthcare sector, as those who leave for other countries are usually highly qualified young people who speak foreign languages.

"Outflows" from the pools of medical doctors and nurses are also caused by decisions to take up a job in Poland but outside of the healthcare sector. A number of determinants of decisions to leave the healthcare sector have already been addressed in the literature [Heinen et al., 2013]; they include economic factors, mainly remuneration, but also non-economic factors connected with the specificity of medical professions, such as: long periods on-duty, night work, working at hospital wards with patients often unable to look after themselves, professional burnout caused, inter alia, by the work which is burdensome and very stressful but offers little development opportunities or a clearly identified career path in the healthcare sector [Haczyński, Ryć, Skrzypczak, Suchecka, 2017]. Responsibility, stress and decreasing prestige of medical professions due to low income plus the need to constantly upgrade one's skills are the reasons why healthcare professionals move to countries which pay higher salaries or decide to seek employment outside of the healthcare sector. Poland is not doing well if we compare the average income of medical doctors and nurses with the average salary in the country or when comparing the salaries of its healthcare workforce with the salaries in the healthcare sectors in other European countries [Skrzypczak, Haczyński, 2016].

According to the OECD, in 2013 in Poland the average remuneration of a medical doctor with specialisation employed full-time represented 1.6 of the average salary in the economy, while in Luxembourg the proportion was 4.2, in Germany and Ireland - 3.7, in the Netherlands - 2.9, in Finland - 2.6, in Denmark - 2.5, and in the UK - 2.4 (OECD, 2015). Currently, employment arrangements for medical doctors include a full-time job contract, a civil law contract, contracts for specified time, short-term contracts when a replacement is needed. There is also the so-called self-employment option when a job contract signed with a private individual becomes a contract with a "company" [Golinowska, Kocot, Sowa, 2013]. There is no sufficient data that could help us calculate the income of doctors and nurses who work under all of these arrangements.

The comparison of the income of nurses employed in hospitals in European countries in 2015 is far from favourable for Polish nurses; their annual income in 2015 was USD 25.8 $\mathrm{k}$ (by purchasing power parity - PPP) while, e.g., the annual income of a nurse employed in a hospital in the Netherlands exceeded USD 66 k, in Ireland - almost USD 63 k, in Belgium - ca. USD 60 k, in Denmark - ca. USD 59 k, in Norway - over USD 54 k, in Germany - more than USD $53.5 \mathrm{k}$, in the UK - almost USD $50.5 \mathrm{k}$, and in France - USD $42.5 \mathrm{k}$ (OECD, 2017).

Besides financial aspects, decisions to leave the country or to give up the medical profession (of a medical doctor or nurse) are motivated by, inter alia, working conditions and professional development perspectives, which are not encouraging in Poland. Specialisation takes a long time, training courses are expensive and they impose an additional burden upon these professional groups. 
SThe sall number of practising doctors per 1,000 population in Poland means they are overworked, which, in turn, impacts the quality of service and increases the referrals to specialist doctors, through which it contributes to even longer queues of patients. According to the OECD data in 2015 the average number of medical consultations of a single doctor in Poland amounted to 3,179, while the average for 32 OECD countries was 2,295. In highly developed European countries an average medical doctor reported, e.g., 692 consultations annually in Sweden, 976 consultations in Norway, 996 in Switzerland, 1,295 in Austria, and 1,310 in Finland. Only in Turkey $(4,651)$, Hungary $(3,810)$ and Slovakia $(3,303)$ doctors reported on average more consultations per year than in Poland [OECD, 2017].

Whenever the shortage of medical services, difficulties in the access to these services and long queues are addressed, people argue more public money should be spent on healthcare. This, actually, is the heart of the problem. Yet, as we can read from the above quoted data, many institutional problems need to be solved to retain in Poland the basic social capital of the healthcare sector, its well-educated resources of doctors and nurses as well as other healthcare professionals who want to work in the healthcare system. Institutional changes, such as more places for students at medical schools, better working conditions of medical professionals, incentives to bring those who have left the country back home, etc., must go hand in hand with growing public spending on healthcare. Only by combining remedy actions in the field of financing and institutional changes may we produce expected results.

\section{Summary}

As we have demonstrated above, in Poland the number of medical doctors and nurses licensed to practise and actually practising their respective professions per 1,000 population is one of the lowest in Europe. That is due to a rather small number of graduates of medical and nursing schools (per 100,000 population) and a considerable "outflow" of medical professionals from the Polish healthcare system to other countries or professions outside of the healthcare sector. Such decisions are usually driven by better remuneration offered in other countries or sectors although non-financial factors, such as hard working conditions or unclear career path in medical professions are also relevant.

The identification and detailed analysis of the reasons why so few doctors and nurses licensed to practise actually work in the healthcare sector may help delineate directions of future actions aimed at changing the healthcare system and the model of training medical professionals, their income, etc. Such actions could produce results within a relatively short time by making medical professions more attractive to ca. $40 \%$ medical doctors and nurses who have the right to practise and either work abroad or have left the healthcare sector. Other actions, targeting medical professionals at retirement or pre-retirement age, may produce effects that will go on for several years. By giving these people, who are often highly skilled specialists, an opportunity to work under different arrangements when retired we could fill 
in the generation gap and ensure passing professional experience from older to younger medical professionals. When it comes to long-term activities over 10 years or longer, we need to increase the population of medical school graduates and reform post-graduate training in medical professions. Improved image and prestige of medical professions, higher remuneration and better working conditions could encourage well educated Polish doctors and nurses to come back to Poland and/or to attract more medical professionals from other countries, especially from Eastern Europe.

\section{References}

1. Araujo E.C., Evans T.G., Maeda A., 2016. Using economic analysis in health workforce policymaking. Oxford Review of Economic Policy, 32(1), pp. 41-63.

2. Buchan J., Wismar M., Glinos I., A. Bremner J. (Eds.) 2014.. Health professional mobility in a changing Europe New dynamics, mobile individuals and diverse responses. Vol. II. The European Observatory on Health Systems and Policies, Observatory Studies Series, 32. Copenhagen: WHO.

3. Centrum Systemów Informacyjnych Ochrony Zdrowia. Biuletyn Statystyczny Ministerstwa Zdrowia, Warszawa 2012-2017. Online: https://www.csioz.gov.pl/statystyka/biuletyn-statystyczny [accessed: 13.11.2017].

4. Czerw A., 2011. Organizacja zasobów ludzkich i planowanie zatrudnienia w podmiotach świadczących działalność leczniczą. Studia i Materiały Polskiego Stowarzyszenia Zarządzania Wiedza; 54, pp. 67-76.

5. Gamzu et al., 2016. Physician Density Planning in a Public Healthcare System: Complexities, Threats and Opportunities-The Case of the Israeli Healthcare System. Health Policy 120(8), pp. 920-927.

6. Golinowska S. (Ed.), 2012. Zarys systemu ochrony zdrowia. Polska. Health Systems in Transition. European Observatory on Health Systems and Policies, WHO.

7. Golinowska S., Kocot E., Sowa A., 2013. Zasoby kadr dla sektora zdrowotnego. Dotychczasowe tendencje i prognozy. Zdrowie Publiczne i Zarzadzanie 11(2), pp. 125-147.

8. Haczyński J., Skrzypczak Z., Winter M., 2017. Nurses in Poland - immediate action needed. Engineering Management in Production and Services, vol. 9(2), pp. 97-104.

9. Haczyński J., Ryć K., Skrzypczak Z., Suchecka J., 2017. Zasoby lekarzy w systemie ochrony zdrowia - Polska na tle wybranych krajów europejskich. Problemy Zarządzania, 3 Vol. 1.

10. Heinen M.M., van Achterberg T., Schwendimann R., Zander B., Matthews A., Kózka M., Ensio A., Stromseng Sjetne I., Moreno Casbas T., Ball J., Schoonhoven L., 2013. Nurses' intention to leave their profession: A cross sectional observational study in 10 European countries. International Journal of Nursing Studies 50, pp. 174-184.

11. Kautsch M., 2013. Migracje personelu medycznego i ich skutki dla funkcjonowania systemu ochrony zdrowia w Polsce. Zdrowie Publiczne i Zarzadzanie 11(2), pp. 169-179.

12. OECD 2015. Health at a Glance 2015, OECD Indicators, Paris: OECD Publishing. Online:

13. http://dx.doi.org/10.1787/health_glance-2015-en [accessed: 21.11.2017]. 
14. OECD 2017. Health at a Glance 2017, OECD Indicators, Paris: OECD Publishing Online: http://dx.doi.org/10.1787/health_glance-2017-en [accessed: 21.11.2017].

15. Skrzypczak Z., Haczyński J., 2016. Wynagrodzenia pielęgniarek w Polsce w latach 2010-2014. Studia i Materialy, 2 part 2; pp. 257-269.

16. World Health Organization. (2016). Global strategy on human resources for health: Workforce 2030. Online: http://who.int/hrh/resources/global_strategy_workforce2030_14_print.pdf?ua=1

17. [accessed: 21.11.2017].

18. Zgliczynski W.S., Cianciara D., Śliż D., Rostkowska O., Pinkas J., 2016. Physicians and dentists - staffing and training system in Poland. Postępy Nauk Medycznych 2016; XXIX (5), pp. 270-278.

Table1. Doctors and nurses with the right to practise their regulated profession employed in the healthcare sector in Poland over the period 2011-2016

\begin{tabular}{|c|c|c|c|c|c|c|}
\hline \multirow[t]{2}{*}{ Year } & \multicolumn{2}{|c|}{$\begin{array}{c}\text { with the right to practise a regulated } \\
\text { profession }\end{array}$} & \multicolumn{2}{|c|}{ employed in the healthcare sector } & \multicolumn{2}{|c|}{$\begin{array}{l}\text { employed shown as a } \% \text { of all } \\
\text { authorised to practise a regulated } \\
\text { profession }\end{array}$} \\
\hline & doctors & nurses & doctors & nurses & doctors & nurses \\
\hline 2011 & 136208 & 282483 & 82376 & 194225 & 60.5 & 68.8 \\
\hline 2012 & 137109 & 285339 & 82944 & 200138 & 60.5 & 70.1 \\
\hline 2013 & 139595 & 279979 & 83371 & 189014 & 59.7 & 67.5 \\
\hline 2014 & 141390 & 282472 & 85789 & 187597 & 60.7 & 66.4 \\
\hline 2015 & 142962 & 285431 & 86533 & 185860 & 60.5 & 65.1 \\
\hline 2016 & 144982 & 288446 & 89819 & 184400 & 62.0 & 63.9 \\
\hline
\end{tabular}

Source: the authors' own compilation based on Biuletyn Statystyczny [Statistical Bulletin] of the Ministry of Health, Centrum Systemów Informacyjnych Ochrony Zdrowia, Warszawa, 2012-2017; https://www.csioz.gov.pl/statystyka/biuletyn-statystyczny [accessed: 15.11.2017].

Diagram 1. Practising doctors per 1,000 population in the European OECD countries in 2000 and 2015

$2000 \square 2015$

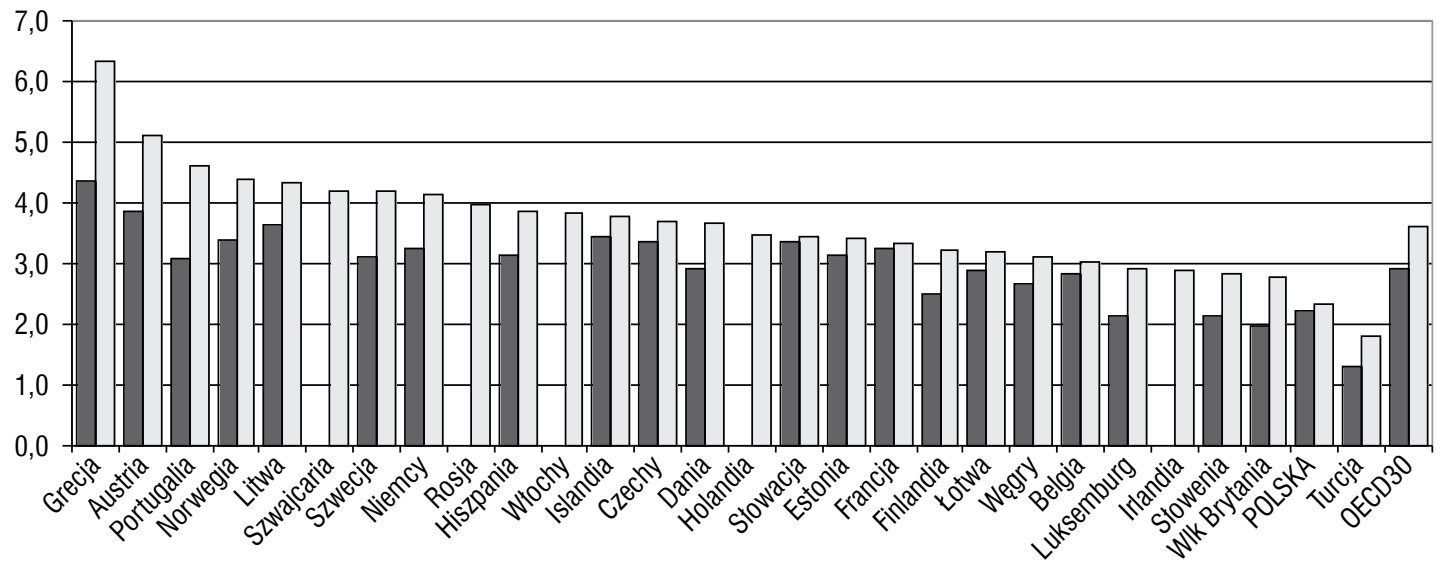

Source: the authors' own compilation based on OECD (2017). Health at a Glance 2017: OECD Indicators. Paris: OECD Publishing. http://dx.doi.org/10.1787/health_glance-2017-en [accessed: 17.11.2017]. 
Diagram 2. Practising nurses per 1,000 population in the European OECD countries in 2000 and 2015



Source: the authors' own compilation based on OECD (2017). Health at a Glance 2017: OECD Indicators. Paris: OECD Publishing. http://dx.doi.org/10.1787/health_glance-2017-en [accessed: 17.11.2017].

Diagram 3. Graduates of medical faculties per 100000 population in European OECD countries in 2015 (or in the last for which data are available)

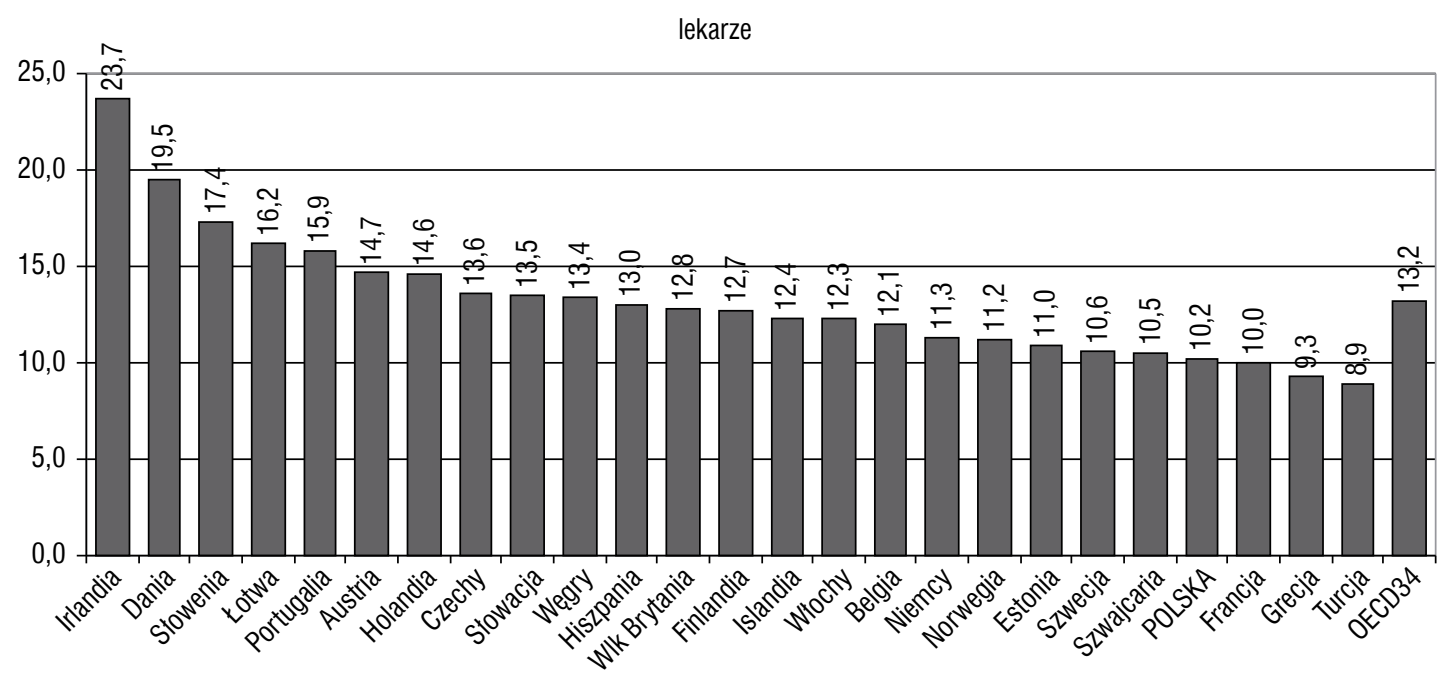

Source: the authors' own compilation based on OECD (2017), Health at a Glance 2017: OECD Indicators. Paris: OECD Publishing. http://dx.doi.org/10.1787/health_glance-2017-en [accessed: 17.11.2017]. 
Diagram 4. Graduates of nursing departments per 100000 population in European OECD countries in $\mathbf{2 0 1 5}$ (or in the last for which the data is available)

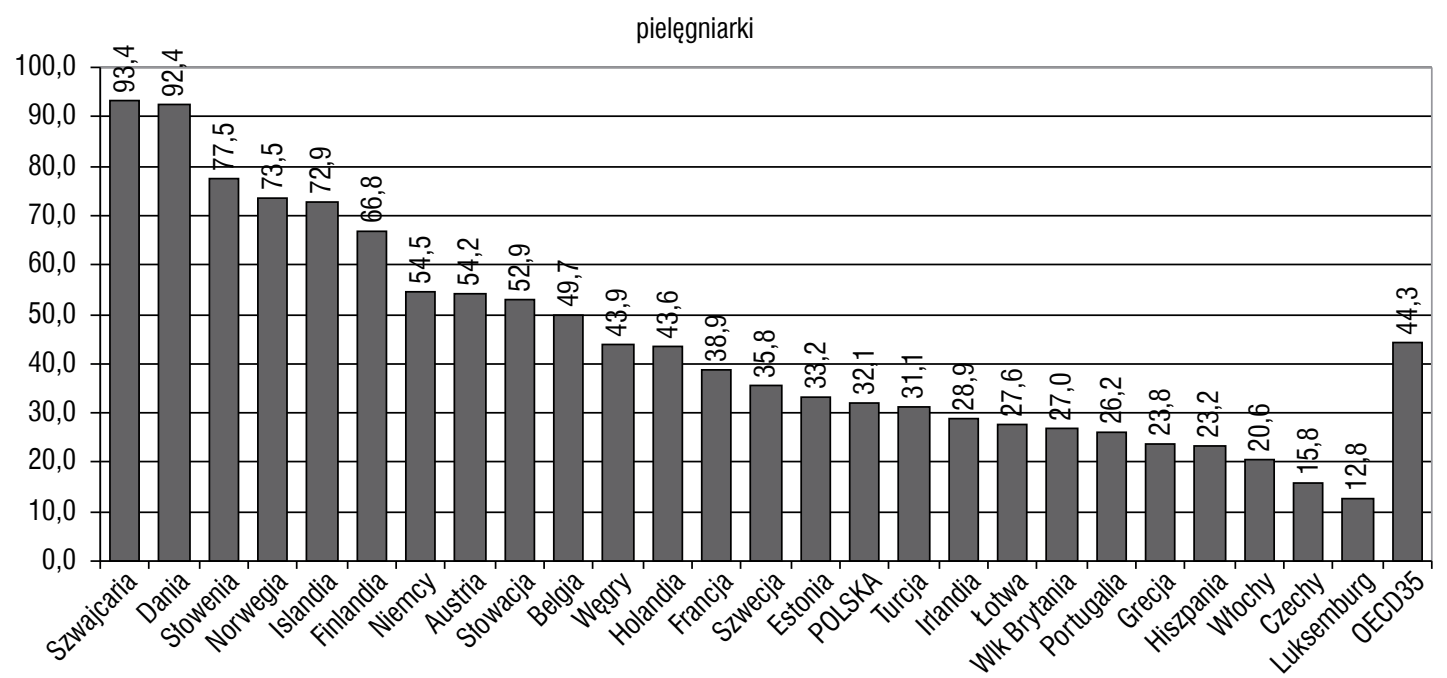

Source: the authors' own compilation based on OECD (2017), Health at a Glance 2017: OECD Indicators. Paris: OECD Publishing http://dx.doi.org/10.1787/health_glance-2017-en [accessed: 17.11.2017].

Diagram 5. Age structure of doctors and nurses licensed to practise the profession in Poland as of 31.12.2016

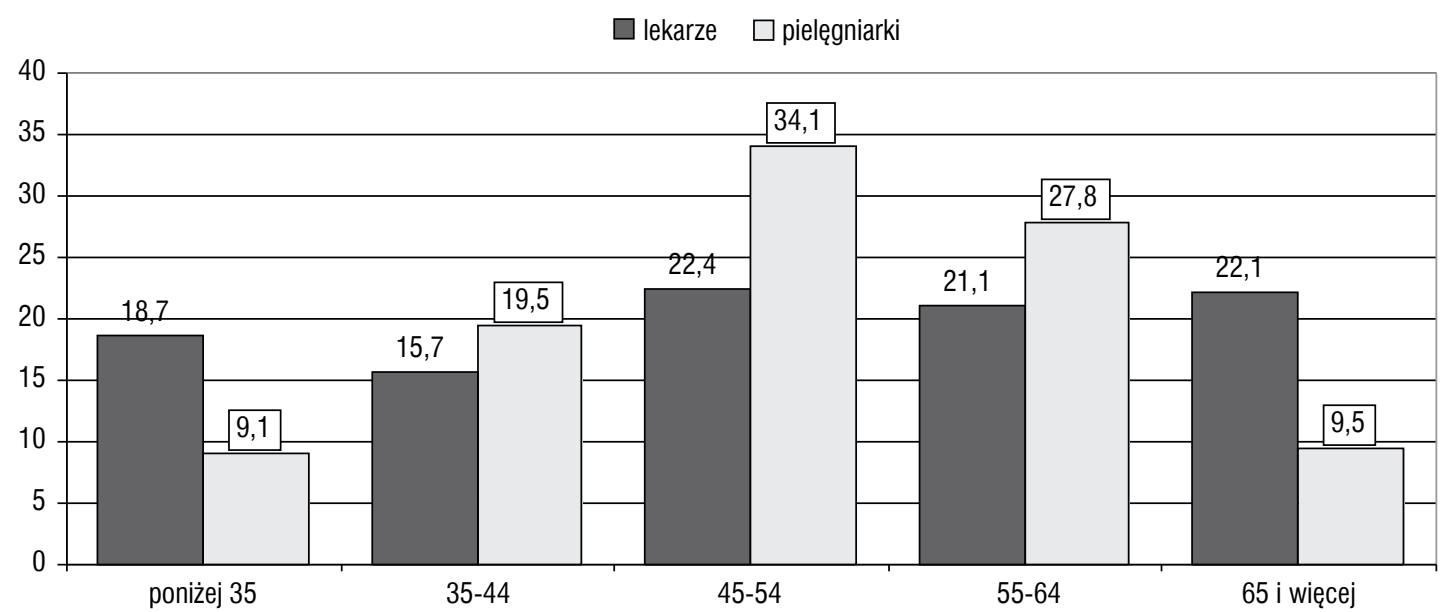

Source: the authors' own compilation based on the Biuletyn Statystyczny [Statistical Bulletin] of the Ministry of Health 2017, CSIOZ Warszawa 2017, www.csioz.gov.pl/staystyka/biuletyn-statystyczny/ [accessed: 15.11.2017]. 